\title{
Victims' Rights in the Diversion Landscape
}

Kay L. Levine

Emory University

Author(s) ORCID Identifier:

https://orcid.org/0000-0002-9422-232X

\section{Recommended Citation}

Kay L Levine, Victims' Rights in the Diversion Landscape, 74 SMU L. REV. 501 (2021)

https://scholar.smu.edu/smulr/vol74/iss3/6

This Article is brought to you for free and open access by the Law Journals at SMU Scholar. It has been accepted for inclusion in SMU Law Review by an authorized administrator of SMU Scholar. For more information, please visit http://digitalrepository.smu.edu. 


\title{
Victims' Rights in THE Diversion LANDSCAPE
}

\author{
Kay L. Levine*
}

\begin{abstract}
In this Article, I explore the practical and theoretical conflicts that might surface when the diversion movement and the Victims' Rights Movement intersect. I focus on two possible sites of tension: victim input into the diversion offer and the victim's right to receive restitution as a term of diversion. Protocols to give victims greater voice in the justice process have been a mainstay of the burgeoning Victims' Rights Movement for the past several decades, but I argue that those protocols must be understood within (and thus limited by) the contexts of fiscal responsibility, compassion for the offender, and proportionality in the justice system that lie at the heart of diversion schemes. Any other arrangement risks elevating retribution over rehabilitation and inserts a level of arbitrariness into the diversion process that would subvert our commitment to fairness and transparency.
\end{abstract}

TABLE OF CONTENTS

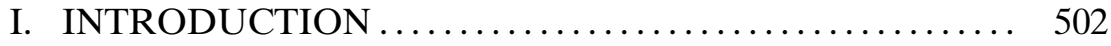

II. THE DIVERSION LANDSCAPE IN THE UNITED STATES ................................. 504

III. THE VICTIMS' RIGHTS MOVEMENT IN THE UNITED STATES ....................... 510

IV. THE COLLISION COURSE BETWEEN DIVERSION AND VICTIMS' RIGHTS .................... 516

A. Victim Input into the Diversion Offer ......... 517

B. Restitution ................................ 521

V. CONCLUSION ................................ 525

* Professor of law, Emory University, School of Law. J.D., 1993, PhD, 2003, U.C. Berkeley; AB Duke University, 1990. The author would like to thank Professors Ron Wright and Erin Collins, who read early versions of this draft, as well as Miriam Krinsky and Liz Komar, who offered their insights both on the draft and during the web conference. This piece is better in so many ways because of their commentary. Thanks also to Maxim Belovol and Ryan Smith, who provided excellent research assistance, and to Judge Jason Marbutt of the Cobb County, Georgia Superior Court, who alerted me to the Cobb County diversion-restitution requirement. Pleae direct comments and questions to klevin2@emory.edu. 


\section{INTRODUCTION}

$\mathrm{M}$ ORE than two decades ago, prosecutors, judges, and legislators realized that the business-as-usual approach to criminal justice was far too costly in terms of human lives and dollars spent for the thousands of people each year who commit relatively minor offenses. Inspired by this realization, they created diversion programs aimed at shuttling low-level offenders out of the criminal legal system at early intercept points, and guided by eligibility standards and program requirements set by prosecutors' offices. ${ }^{1}$ The development of diversion programs thus represented the convergence of several ideals that previously had been subordinated to law-and-order policymaking: a concern for fiscal responsibility, a greater sense of compassion for low-level offenders, and a commitment to proportionality in criminal justice. ${ }^{2}$

But by the time diversion programs were emerging in the late 1990s, a strong countercurrent was already underway. The Victims' Rights Movement, which began in earnest in the mid-1970s, insisted that crime victims would no longer tolerate being ignored. The movement led to the enactment of statutory "victims' bills of rights" and constitutional amendments in many states in the United States in the 1980s and 1990s. ${ }^{3}$ A federal constitutional amendment was also proposed, but it never gained much traction due to the inherent conflict with many provisions of the Sixth Amendment and the level of activity already happening in the states to protect victims' interests. ${ }^{4}$ Recently the victims' rights initiative has taken on new urgency, with a wave of state constitutional amendments known as "Marsy's Laws" seeing passage via voter referendums in various jurisdictions. ${ }^{5}$

While both the diversion movement and the Victims' Rights Movement seek to reform the criminal legal system and to dislodge what reformers

1. Ronald F. Wright \& Kay L. Levine, Models of Prosecutor-Led Diversion Programs in the United States and Beyond, 4 Ann. Rev. CRiminology 331, 334, 338 (2021).

2. 21 Principles for the 21st Century Prosecutor, Brennan CTR. FOR Just. 5, 24, 25 (Dec. 3, 2018), https://www.brennancenter.org/sites/default/files/2019-08/Report_21st_century_prosecutor.pdf [https://perma.cc/Z7GX-4C3V]; Winifred Agnew-Pauley, Diversion in the Criminal Justice System: Examining Interventions for Drug-Involved Offenders, in REthinking Drug Courts: International Experiences of a US Policy Export 123, 124 (John Collins, Winifred Agnew-Pauley \& Alexander Soderholm eds., 2019) ("The motivations for implementing diversion programmes are varied and wide-ranging, including, for example, introducing a greater emphasis on public health outcomes; addressing the stigma associated with, and the criminogenic influence of, formal contact with the CJS; lessening the burden on criminal justice resources, such as overcrowded prisons; and improving the cost-effectiveness of the CJS." (citation omitted)).

3. Aileen Adams \& David Osborne, Victims' Rights and Services: A Historical Perspective and Goals for the Twenty-First Century, 33 McGeorge L. Rev. 673, 675-76 (2002).

4. Robert P. Mosteller, The Unnecessary Victims' Rights Amendment, 1999 Utah L. REv. 443, 465-66.

5. See generally Paul G. Cassell \& Margaret Garvin, Protecting Crime Victims in State Constitutions: The Example of the New Marsy's Law for Florida, 110 J. CRIM L. \& CRIMINOLOGY 99 (2020). 
see as outdated principles and practices, these two movements offer orthogonal (and sometimes conflicting) visions for reform. It is no doubt true that many victims support rehabilitation over punishment, both as an abstract ideal and in their own lives. ${ }^{6}$ But the Victims' Rights Movement seems not to capture those voices, as it seem to embody a preference for retributivism over rehabilitation, for cages over services, and for vindictiveness over shared humanity. For that reason, the claims of the Victims' Rights Movement suggest the legal system should ignore or undermine fiscal responsibility, proportionality, and compassion for the offenderthe very hallmarks of diversion. In short, the potential irreconcilability of diversion principles and victims' rights claims puts legislators and prosecutors in a bind as to which road to follow. The fact that victims are a politically popular constituency ${ }^{7}$ (and criminal defendants are not) makes the issue ripe for outside input, given that legislators and chief prosecutors in most jurisdictions seek reelection on a regular basis.

In order to limit the likelihood that resolution of these questions will be driven by political expediency rather than integrity, ${ }^{8}$ scholars ought to weigh in on whether victims should be included in the creation and implementation of diversion schemes. The answer is not a binary yes-or-no choice because even if we conclude that victims deserve a seat at the table, we might have to impose limits on victim input in order to prevent the erosion of diversion's foundational principles. As Kristin Henning observed in the context of the juvenile justice system, "As long as rehabilitation remains an important and viable objective ... [,] legislators must carefully consider how victims' rights will advance or undermine this objective." 9

While the impact of the Victims' Rights Movement on the criminal legal system has been a mainstay of scholarship for several decades, ${ }^{10}$ this Article brings that conversation to the diversion programming context.

6. All. for SAfety \& Just., Crime Survivors Speak: The First-Ever National Survey of Victims' Views ON SAfETy AND Justice 15 (2016) (finding that victims support rehabilitation over punishment by a two-to-one margin). That this paper does not deal with the conflicts that might arise when a victim wants the offender to receive diversion but the program eligibility rules do not permit it, based on the offender's crime or criminal history.

7. Mosteller, supra note 4, at 474-75; see also Janice Nadler \& Mary R. Rose, Victim Impact Testimony and the Psychology of Punishment, 88 Cornell L. Rev. 419, 453 (2003) (observing that prosecutors have shifted towards using more victim impact evidence); James A. Blanco, Reparation and Restitution: Louisiana's Response to the Victims' Rights Movement, 33 Loy. L. REv. 393, 398 (1987) (declaring that advocacy in support of victims' rights legislation in the 1970s and 1980s became "politically popular, bipartisan, and national in scope").

8. Even if prosecutor elections have historically tended not to be contentious, see Ronald F. Wright, How Prosecutor Elections Fail Us, 6 Оніо ST. J. CRiм. L. 581, 592-94 (2009), prosecutors still tend to make decisions with an eye toward reelection impact.

9. Kristin Henning, What's Wrong with Victims' Rights in Juvenile Court?: Retributive Versus Rehabilitative Systems of Justice, 97 CALIF. L. Rev. 1107, 1122 (2009).

10. See, e.g., Charles F. Baird \& Elizabeth E. McGinn, Re-Victimizing the Victim: How Prosecutorial and Judicial Discretion Are Being Exercised to Silence Victims Who Oppose Capital Punishment, 15 Stan. L. \& Pol'y Rev. 447, 448-55 (2004); Susan Bandes, Empathy, Narrative, and Victim Impact Statements, 63 U. CHI. L. REv. 361, 366-80 (1996). For a 
After providing the reader a quick tour through the diversion landscape in Part II and the Victims' Rights Movement in Part III, I examine two points of intersection in Part IV. I first take up the question of victim input into the diversion offer. I contend that providing victims notice and an opportunity to confer on case resolution is an important feature of the victims' rights agenda, and it should be extended to the diversion context. But providing victims a veto goes beyond seeking their input-it would inappropriately allow the victim to block the offer of diversion to a defendant who is otherwise considered eligible and suitable for the program. I next address the inclusion of restitution in the diversion program scheme. Restitution is regularly mentioned as a right of the victim in statutory and constitutional provisions, but it tends to be in reference to adjudication outcomes. Because diversion is quite plainly not adjudication, how restitution applies is a question that prosecutors' offices must decide without legislative direction. After considering the benefits and burdens of requiring that the defendant make full payment before enrollment, I advocate for more flexibility during the diversionary period rather than stringent up-front payment.

In short, I subscribe to a model of diversion that prohibits the victim's veto over whether the defendant can participate and refrains from imposing full payment of restitution up front as a condition of participation. Both requirements seem to tip the scales in favor of retribution and full prosecution, thereby undermining recent efforts to limit the reach of the criminal legal system. ${ }^{11}$ Moreover, victim veto and restitution requirements introduce arbitrariness, based on either victim attitude (taste for compassion versus taste for revenge) or defendant wealth (financial ability versus inability to pay the full amount immediately). Neither form of arbitrariness is acceptable, particularly in an era when we are seeking avenues to increase fairness and transparency in decision-making and to decrease the impact of the legal system on already-disadvantaged communities. For those reasons, I conclude that while victims' interests ought to be considered when diversion programs are created and prosecutors ought to consult with victims before offering diversion, we should limit the degree to which victims can influence the allocation of diversion resources among the offender population.

\section{THE DIVERSION LANDSCAPE IN THE UNITED STATES}

Formalized programs to divert potential defendants out of the criminal courts and into treatment or community service emerged in the United

bibliography on the subject, see Jean M. Callihan, Victim Impact Statements in Capital Trials: A Selected Bibliography, 88 Cornell L. Rev. 569 (2003).

11. These efforts were initiated once policymakers acknowledged that "bars can't build better men," Stuart Turton, The $71 / 2$ Deaths of Evelyn Hardcastle 436 (2018), and are too costly to provide so little in return on the recidivism front, see Robert E. Wright, Reducing Recidivism 3-4 (Nov. 18, 2020) (unpublished manuscript), available at https://papers.ssrn.com/sol3/papers.cfm?abstract_id=3733040 [https://perma.cc/B2TUDNVV]. 
States in the mid-twentieth century, spurred by a 1967 report from the President's Commission on Law Enforcement and the Administration of Justice. ${ }^{12}$ Judges and prosecutors collaborated to create the earliest diversion programs, ${ }^{13}$ but eventually prosecutors created diversion programs that did not involve judges at all. Judges instead took the reins on crafting problem-solving or accountability courts for specialized issues like drug use or criminal behavior by veterans. ${ }^{14}$

There were a few fledgling programs in the 1970s and 1980s, but the law-and-order headwinds, fueled by media-driven fear of crime and the War on Drugs, were overpowering, and the evaluation data from the early programs were not encouraging. ${ }^{15}$ The idea of diversion did not gain steam in the United States until the late 1990s and early 2000s, ${ }^{16}$ when policymakers could no longer hide from the fact that full prosecution was far too expensive of an approach for many offenders caught up in the legal system. ${ }^{17}$ Aggressive punishment approaches relying heavily on incarceration had squeezed the budgets of state and local governments since the politics of law and order took hold in the 1970s. ${ }^{18}$ Such spending might have made fiscal sense if most offenders needed this heavy-handed approach to deter them from future law-breaking. But many offenders respond to more moderate interventions-or sometimes need no intervention at all19-thus establishing the gross inefficiency of the "full prosecution for everyone" model. And on the flipside, even the fullprosecution approach was (and remains) unproven as a mechanism of crime control-its ability to reduce re-offending has never been established empirically. ${ }^{20}$

12. President's Comm'n on L. Enf't \& Admin. of Just., The Challenge of Crime in a Free Society 133-34 (1967).

13. See, e.g., State v. Leonardis, 363 A.2d 321, 325 (N.J. 1976).

14. Wright \& Levine, supra note 1 , at 332, 336. See generally Erin R. Collins, The Problem of Problem-Solving Courts, 54 U.C. DAvis L. Rev. 1573 (2021).

15. See Malcolm M. Feeley, Court Reform on Trial: Why Simple Solutions FAIL 84-87, 93-102, 105-06 (1983).

16. Diversion programs also exist in many other countries, see Wright \& Levine, supra note 1, at 338-40 (discussing programs in the United Kingdom, Western Europe, South Africa, and Japan, for example), but the focus of this Article is on diversion programs in the United States.

17. See Michael Rempel, Melissa labriola, Priscillia Hunt, Robert C. Davis, Warren A. Reich \& Samantha Cherney, NiJ's Multisite Evaluation of Prosecutor-Led Diversion Programs: Strategies, Impacts, and Cost-Effectiveness 1-2 (2018), https://www.ojp.gov/pdffiles1/nij/grants/251665.pdf [https://perma.cc/ACE5-X83T].

18. Nat'l Rsch. Council, The Growth of Incarceration in the United States: Exploring CAuses AND ConseQuences 111-13 (Jeremy Travis, Bruce Western \& Steve Redburn eds., 2014). John Pfaff has argued that prosecutors are directly to blame because they filed more and more cases as felonies in the 1990s than ever before. JoHN F. Pfaff, Locked In: The True Causes of Mass Incarceration-and How to Achieve Real Reform 73-74 (2017).

19. See John H. Laub \& Robert J. Sampson, Understanding Desistance from Crime, 28 Crime \& Just. 1, 6 (2001); Franklin E. Zimring, American Juvenile Justice 50-52 (2d ed. 2019).

20. See generally Wright, supra note 11 , for a collection of studies documenting the relationship between incarceration and recidivism. 
The conventional approach to criminal justice did more than just cause a significant fiscal impact on state budgets. It also forced upon prosecutors a binary choice: file a case and proceed to full prosecution, or decline to file and let the defendant go free with no strings attached. But this either/or proposition was too limited for a large number of the police reports that crossed prosecutors' desks, because the offender population is heterogeneous when it comes to background, amenability to treatment, and risk of causing future harm. ${ }^{21}$ Given the myriad variations in defendants, "[prosecutors sought] softer approaches for those whose backgrounds suggest[ed] that little [would be] needed to incentivize lawabiding behavior in the future." 22 Furthermore, prosecutors came to recognize that the collateral consequences of conviction can unfairly stigmatize and constrain the life choices of defendants long after they have finished serving the sentence imposed by the criminal court. ${ }^{23}$

To put it simply, what prosecutors needed was a way to shuttle minor offenders out of the criminal legal system before trial, while still keeping an eye on them from a short or long distance. Inspired by three bedrock principles-compassion for the offender, proportionality in criminal justice response, and fiscal responsibility - they devised diversion programs to do just that. ${ }^{24}$ We now have hundreds of diversion programs in county prosecutors' offices across the United States, covering crimes like drug use, prostitution, theft, and DUI. ${ }^{25} \mathrm{We}$ also have specific programs for offenders with mental health issues and for juveniles. ${ }^{26}$ Programs for those who commit felony offenses also exist, although they are more rare

\footnotetext{
21. Wright \& Levine, supra note 1 , at 334.

22. $I d$.

23. For example, even misdemeanor convictions, including almost all drug possession convictions, can subject an individual to deportation; create barriers to employment, housing, and educational opportunities; and detrimentally impact a person's ability to access credit. Jenny Roberts, Prosecuting Misdemeanors, in Oxford Handbook of Prosecutors And Prosecution 25.1, 25.2.2 (Ronald F. Wright, Kay L. Levine \& Russell M. Gold eds. 2021); Abhay P. Aneja \& Carlos Avenancio-León, No Credit for Time Served? Incarceration and Credit-Driven Crime Cycles 2 (July 2020) (unpublished manuscript), https:// static1.squarespace.com/static/59dc0ec564b05fea9d3dfee3/t/5f11d977797b7f4875d36537/ 1595005305683/IncarcerationAccessToCredit_v07102020.pdf [https://perma.cc/X8C72QFK] (finding that "ex-convicts face a drop of between 42 to 57 points in their credit scores, reductions in their auto loan financing of around 25 percentage points (p.p), and declines in mortgages of around 20 p.p.").

24. See supra note 2 and accompanying text.

25. For a sketch of crime-based programs, see REMPEL ET AL., supra note 17, at 14-23 (reviewing the Small Amount of Marijuana Program and Accelerated Misdemeanor Program in Philadelphia, Pennsylvania; the Treatment Accountability for Safer Communities program for drug cases in Maricopa County, Arizona; the Cook County Drug School and the Cook County Misdemeanor Diversion Program in Chicago, Illinois; Operation de Novo for property and drug offenses in Minneapolis, Minnesota; and a similar program in Dallas, Texas for retail theft offenses). See also Cory R. Lepage \& Jeff D. May, The Anchorage, Alaska Municipal Pretrial Diversion Program: An Initial Assessment, 34 Alaska L. Rev. 1, 10 (2017) (highlighting a program in Anchorage, Alaska for first-time property offenders with no history of drug or alcohol dependency).

26. See Wright \& Levine, supra note 1, at 343-44 (citing sources that have evaluated various kinds of diversion programs for juveniles and offenders with mental health problems).
} 
and are usually off limits to those who commit crimes of violence. ${ }^{27}$ The short-term goal of these programs is to have the defendant complete the program and wipe the criminal offense from his or her record permanently. ${ }^{28}$ The long-term goal is to help the defendant desist from criminal behavior in the future, thereby improving his or her individual well-being, as well as downsizing the financial footprint of the courts and carceral facilities. $^{29}$

Diversion programs designed and operated by prosecutors offer defendants a chance to exit the legal system either before a case is filed, post-filing but before a plea, or after a plea but before a sentence is imposed. ${ }^{30}$ But the gift of early exit is not a truly free one. The diversion program imposes some responsibility on defendants for making amends and changing their behavior: in order to have the case permanently dismissed, a defendant usually must complete a designated number of community service hours, submit to drug testing, pay restitution to the victim, and/or participate in an educational program. ${ }^{31}$ This collection of requirements, designed by the prosecutor's office ostensibly to help the defendant make better choices in the future, is the means by which prosecutors keep an eye on the defendants who have been diverted out. Of course, the more components that are embedded in the diversion program, the more challenging it is for the defendant to complete it. ${ }^{32}$ These behavioral expectations and requirements make diversion distinct from declination because when charges are rejected, the individual remains free to live his or her life without surveillance.

Diversion differs from declination in two other important ways. First, defendants who fail to complete the program requirements may find

27. Michela Lowry \& Ashmini Kerodal, Ctr. for Ct. Innovation, Prosecutor-Led Diversion: A National Survey iv (2019) (reporting that just over half of the 220 jurisdictions they surveyed had programs for non-violent felonies). But see REMPEL ET AL., supra note 17, at 24, for a description of the Cook County Felony Diversion Program, which does include some violent felonies, and see David Noble, Executive Summary of the Institute for Innovation in Prosecution (IIP) Diversion Roundtable, 5 CRIM. L. PRAC. 78, 87 (2020), for a description of diversion programs with restorative justice features in some of the boroughs of New York. Extending diversion opportunities to those who commit violent crimes is consistent with the message offered by David Sklansky in his new book, DAviD Sklansky, A Pattern of Violence: How the Law Classifies Crimes and What It MeAns for Justice (2021).

28. See Lowry \& Kerodal, supra note 27, at 16 . However, even an arrest that is later dismissed might still be listed on a state's public criminal records database, searchable by a potential employer or landlord. Marina Duane, Nancy La Vigne, Mathew Lynch \& Emily Reimal, Criminal Background Checks: Impact on Employment and RecidiVISM 6 (2017).

29. See Lowry \& Kerodal, supra note 27, at 16.

30. See Erica McWhorter \& David LaBahn, Confronting the Elephants in the Courtroom Through Prosecutor Led Diversion Efforts, 79 AlB. L. Rev. 1221, 1226 (2016).

31. Lowry \& Kerodal, supra note 27 , at 18.

32. Because the program components can be onerous, one commentator has referred to them as akin to "probation before trial." Note, Pretrial Diversion from the Criminal Process, 83 YAle L.J. 827, 843 (1974). Another has warned that when program components do not track program objectives, they risk becoming a form of "correctional quackery.” Edward J. Latessa, Shelley L. Johnson \& Deborah Koetzle, What Works (And Doesn't) in Reducing Recidivism 79 (2d ed. 2020). 
themselves back on the court's docket for full prosecution, and the results of full prosecution at that point might be harsher than what the defendant might have originally faced. ${ }^{33}$ Second, when jurisdictions create diversion programs, police officers sometimes end up making more arrests for divertible offenses than they otherwise would have because they need to do their part to keep the programs in business. ${ }^{34}$ These patterns have led to accusations that diversion programs widen the net of criminal justice intervention ${ }^{35}$ - they motivate and provide tools for the legal system to identify and monitor offenders who otherwise would have been left to go about their business unhindered.

Irrespective of these concerns, prosecutors tend to think of diversion as a gift, albeit with strings attached. Because it is a gift, not every offender is given the chance to receive it. Prosecutors design eligibility criteria for such programs, ${ }^{36}$ which typically include severity ceilings for the crime alleged and proof of no substantial criminal record. ${ }^{37}$ Among those who meet the technical eligibility requirements, only those determined "suitable" will be offered diversion, because prosecutors want to make sure that a defendant has a reasonable chance to take full advantage of the gift before they offer it.

The eligibility rules and the suitability screens appear objectively neutral, but a closer inspection reveals their embrace of and tendency to reinforce certain troubling patterns. First, these screens funnel the most likely success stories into the program while keeping higher-risk populations out. ${ }^{38}$ In so doing, they embody a form of selection bias that helps to create the impression that the program itself generates a reduction in recidivism. In other words, prosecutors want the cream of the crop to par-

33. Lynne Roberts \& David Indermaur, Timely Intervention or Trapping Minnows? The Potential for a Range of Net-Widening Effects in Australian Drug Diversion Initiatives, 13 Psychiatry, Psych. \& L. 220, 227 (2006) ("[S]anctions imposed during the course of the 'treatment' may exceed the likely sentence. . . . In some cases, the accumulation of sanctions ... can exceed the length of sentence that may initially have been imposed if diversion had not occurred.").

34. David R. Lilley, Did Drug Courts Lead to Increased Arrest and Punishment of Minor Drug Offenses?, 34 Just. Q. 674, 676-77 (2017).

35. See Issa Kohler-Hausmann, Misdemeanorland: Criminal Courts and Social Control in an Age of Broken Windows Policing 244 (2018); Jamie S. Gorelick, Pretrial Diversion: The Threat of Expanding Social Control, 10 HARv. C.R.-C.L. L. Rev. 180, 194 (1975); Thomas G. Blomberg, Gary R. Heald \& Mark Ezell, Diversion and Net Widening: A Cost-Savings Assessment, 10 Eval. Rev. 45, 58-59 (1986); Roberts \& Indermaur, supra note 33, at 229; Note, supra note 32, at 836.

36. Note that, in most instances, these are not statutory rules; they are features of the programs that prosecutors design. Wright \& Levine, supra note 1, at 337.

37. Id. at 338-39 (describing eligibility standards generally and severity ceilings in particular). On the issue of prior record, see Rempel ET AL., supra note 17, at 17. Of the sixteen programs reviewed, all limited admission to those with no prior felony convictions. See also Nat'l Ass'n of Pretrial Servs. Agencies, Pretrial Diversion in the 21st Century: A National Survey of Pretrial Diversion Programs and Practices 16-17 (2009) (concluding the majority of programs surveyed were open only to defendants with either no prior convictions or no prior felony convictions).

38. See Celesta A. Albonetti \& John R. Hepburn, Prosecutorial Discretion to Defer Criminalization: The Effects of Defendant's Ascribed and Achieved Status Characteristics, 12 J. Quantitative Criminology 63, 66-67 (1996). 
ticipate in the program because selectivity increases the chance that the program can report higher levels of success (defined as lower rates of rearrest when compared to nonparticipants). ${ }^{39}$ But if program participants are better poised to achieve success than those who are not invited to participate even before the program begins, we cannot really know the effect of the program on changing behavior. When prosecutors' eligibility and suitability protocols are guided by concerns for program success rather than fairness, they also tend to tip the scales in favor of making diversion offers to Caucasians and younger defendants. ${ }^{40}$ This is not an allegation of intentional discrimination but rather an observation that the program's institutional design can cause a discriminatory effect. Persons of color and older defendants are more likely to wash out of diversion due to a new arrest, or to get re-arrested a short time afterwards, ${ }^{41}$ thereby tarnishing the reputation of the program. When making these choices, prosecutors give very little thought to whether arrest patterns are generated by policing patterns, rather than by offense behavior patterns. ${ }^{42}$ Finally, fee requirements often keep diversion programs out of reach for extremely poor defendants. Even if they are otherwise suitable, those who cannot pay fees for classes and drug tests are routinely denied admission. ${ }^{43}$

Suitability screens have thus come under scrutiny for unfairly keeping out subsets of the defendant population who otherwise deserve a chance to participate; prosecutors do not want to risk program success levels by including offenders who are statistically more likely to get re-arrested within a fairly short time. ${ }^{44}$ The desire for program success overrides the desire to give certain offenders a chance to succeed. To the extent these programs depend on a narrative that defines success as reduced rates of re-arrest, a narrative that is central to the fiscal-responsibility foundational premise of diversion itself, this result is not surprising. But it does suggest that compassion and proportionality are subordinate foundational premises, because they may be forced to yield to fiscal responsibility when there is a conflict between them.

39. The empirical evidence about the success of diversion programs is decidedly mixed, but that topic is beyond the scope of this Article. See Wright \& Levine, supra note 1 , at 339 .

40. See Traci Schlesinger, Racial Disparities in Pretrial Diversion: An Analysis of Outcomes Among Men Charged with Felonies and Processed in State Courts, 3 RACE \& Just. 210, 228-29 (2013); Albonetti \& Hepburn, supra note 38, at 66-67; see also Shaila Dewan \& Andrew W. Lehren, After a Crime, the Price of a Second Chance, N.Y. Times (Dec. 12, 2016), https://www.nytimes.com/2016/12/12/us/crime-criminal-justice-reform-diversion.html [https://perma.cc/Z7XU-T668] (noting that in the Memphis juvenile diversion program, whites are more likely to get diversion offers than African Americans).

41. See Albonetti \& Hepburn, supra note 38, at 78.

42. See id.

43. Dewan \& Lehren, supra note 40; Noble, supra note 27, at 90.

44. Dewan \& Lehren, supra note 40. 


\section{THE VICTIMS' RIGHTS MOVEMENT IN THE UNITED STATES}

Before our nation's founding, when criminal law still bore strong linkages to tort law ${ }^{45}$ local criminal laws were enforced by victims, and the state's role was limited to imposition of punishment. ${ }^{46}$ In this system of private prosecution, a crime inflicted a debt that was owed to the victim, and the criminal case was viewed as a mechanism to provide compensation to the victim for that debt. ${ }^{47}$ Because the victim-offender dyad was at the center of the case, the victim had control over whether a case was brought, including responsibility for conducting the investigation to establish the wrongdoer's guilt. ${ }^{48}$ If victims chose to forego prosecution, there was no public agency that would carry it forward in their name. ${ }^{49}$ But private prosecutions fell out of favor as American cities developed; they were inefficient, victims were too inexperienced to investigate and prosecute random actions by wrongdoers, and society writ large became the primary holder of the debt caused by the defendant's misbehavior. ${ }^{50}$ Public prosecutors were thus appointed and assumed control over the power to prosecute most crimes by the start of the nineteenth century, a model that still exists today.

With public prosecutors in charge of decision-making, victims were forced to assume a secondary, subordinate role in prosecution. ${ }^{51}$ As the Supreme Court stated in 1973, in a case involving failure to provide child support, victims have no standing to file a criminal complaint:

[I]n American jurisprudence at least, a private citizen lacks a judicially cognizable interest in the prosecution or nonprosecution of another. . . . [G]iven the special status of criminal prosecutions in our system, we hold that appellant has made an insufficient showing of a direct nexus between the vindication of her interest and the enforcement of the State's criminal laws. ${ }^{52}$

45. Kay Levine \& Malcolm Feeley, Prosecution, 19 InT'L Encyclopedia Soc. \& Behav. Scis. 210, 210 (2015) (citing John H. Langbein, Prosecuting Crime in the Renaissance: England, Germany, France 225 (1974) (identifying the origins of criminal law in tort law)).

46. Douglas E. Beloof \& Paul G. Cassell, The Crime Victim's Right to Attend the Trial: The Reascendant National Consensus, 9 Lewis \& Clark L. Rev. 481, 484-85 (2005); Cassell \& Garvin, supra note 5, at 102-03 (2020) (citing William F. McDonald, Towards a Bicentennial Revolution in Criminal Justice: The Return of the Victim, 13 Aм. CRIM. L. Rev. 649 (1976)).

47. See Blanco, supra note 7, at 394.

48. Id.

49. See id. at 394-95.

50. Id. at 395-96; Henning, supra note 9, at 1110 (citing PegGy M. Tobolowsky, Crime Victim Rights and Remedies 5-6 (2001)); Cassell \& Garvin, supra note 5, at 102-03 (first citing Stephanos Bibas, The Machinery of Criminal Justice (2012); then citing Abraham S. Goldstein, Defining the Role of the Victim in Criminal Prosecution, 52 Miss. L.J. 515, 549 (1982)).

51. Some commentators link the diminished status of victims to a system-wide emphasis on offender rehabilitation in the 1950s and 1960s. See, e.g., Albert R. Roberts, Victim/ Witness Programs: Questions and Answers, 61 FBI L. EnF'T Bull. 12, 13 (1992).

52. Linda R.S. v. Richard D., 410 U.S. 614, 619 (1973). 
In a public prosecution scheme that defines society as the holder of the debt (and thus the only holder of a judicially cognizable interest), victims are limited to the role of witness; they can speak from the witness stand or when seeking restitution for damages suffered, but at no other point. In this capacity victims sometimes feel traumatized by the legal system itself, over and above what they suffered at the hands of their alleged assailants-whether by police who ignore or downplay their calls for help, by prosecutors who disregard them, or by defense attorneys who subject them to stinging cross-examination. ${ }^{53}$ Moreover, once limited to the role of witness, the victim can no longer steer the case; a victim's input will be sought only as a courtesy by a prosecutor who is inclined to ask for it. ${ }^{54}$ In this environment, many victims believe the legal system expresses only "institutionalized disinterest" with respect to their needs and concerns. ${ }^{55}$ Victims who want more involvement can file civil lawsuits for damages, but to do so they need to hire their own attorneys. ${ }^{56}$

Starting in the mid-twentieth century, this state of affairs struck many displaced victims as deeply unsatisfying, ${ }^{57}$ leading them to form a social movement in support of victims' rights. Paul Cassell and Margaret Garvin report that adherents hailed from diverse segments of society, including those striving for women's rights, civil rights, and increased law and order in the nation. ${ }^{58}$ That Victims' Rights Movement gained momentum through the 1970s and $1980 \mathrm{~s}^{59}$ fueled by increased media attention on crime and criminals, which in turn drove up rates of fear of crime among the American public. ${ }^{60}$ Well-publicized horrific crimes against children in the 1980s, though extremely rare, coupled with the Reagan Administra-

53. Roberts, supra note 51, at 13.

54. See Levine \& Feeley, supra note 45, at 210-11 (describing the shift from private prosecution to public prosecution in the U.S. and in other nations, and the vestiges of private prosecution that remain in various nations).

55. Blanco, supra note 7, at 396 (quoting President's Task Force on Victims of Crime, Final Report vi (1982)).

56. Id. at 395-96 (citing Juan Cardenas, The Crime Victim in the Prosecutorial Process, 9 Harv. J. L. \& Pub. POL’Y 357, 371-72 (1986)).

57. See Henning, supra note 9 , at 1110 (citing Tobolowsky, supra note 50, at 7) ("[A]ctivists complained that victims had no voice in the prosecutorial process, were not being treated with sensitivity and respect by police and prosecutors, and were not being provided with adequate restitution or services ....").

58. Cassell \& Garvin, supra note 5, at 103; see also John P. J. Dussich, Teaching Victimology in America: From on the Job Training (OJT) to PhD, 25 J. CRIM. Just. Educ. 486, 487 (2014) (describing the social events that "contributed to the heightened public and academic awareness of crime victimization," including the post-war baby boom, the crime wave of the 1960s and 70s, the civil rights and feminist movements, the Vietnam War, and a renewed emphasis on social problems by the federal Law Enforcement Assistance Administration).

59. The Victims' Rights Movement was also international in scope, as many human rights instruments adopted during this period addressed the rights of crime victims. Hum. Rts. Watch, Mixed Results: US Policy and International Standards on the Rights AND INTERESTS OF Victims OF CRIME 9-10 (2008), https://www.hrw.org/report/ 2008/09/23/mixed-results/us-policy-and-international-standards-rights-and-interests-victims [https://perma.cc/EE8N-K6ZB].

60. Blanco, supra note 7, at 396-97. 
tion's War on Drugs, ${ }^{61}$ kept crime constantly on the public agenda, just as support for rehabilitation programs waned. Furthermore, the efforts of the Warren Court to expand procedural protections for criminal offenders produced a backlash in succeeding decades, some of which centered on the need for victims to have rights too. ${ }^{62}$

In terms of policy achievements, the Victims' Rights Movement can point to a remarkable number of successes. Those successes began on the West Coast in 1965, when California created the first victim compensation fund. ${ }^{63}$ Seven years later, Bay Area Women Against Rape was founded in San Francisco to provide victim services. ${ }^{64}$ Today, every state has a victims' compensation fund, and there are thousands of victim service agencies across the country. ${ }^{65}$ Just under $20 \%$ of those agencies are housed within prosecutors' offices, ${ }^{66}$ an approach that began with grants from the federal Law Enforcement Assistance Administration in the $1970 s^{67}$ but that today is supported largely through state and local funding, as well as penalty assessments on convicted offenders. ${ }^{68}$ Victim and witness assistance bureaus in prosecutors' offices tend to be run by professionals who hold college degrees in criminal justice, sociology, or counseling; some units are staffed by personnel who used to hold secretarial or administrative positions within the prosecutor's office before moving into the specialized bureau. ${ }^{69}$ Irrespective of the staffing model, these bureaus encourage and facilitate witness cooperation with the prosecution from filing to testifying, advise of court dates and continuances, and assist with reimbursement for costs incurred due to the crime. ${ }^{70}$

In addition to innovating direct service and support models for victims, California led the way in expanding its formal law to offer victims the

61. Andrew Glass, Reagan Declares “War on Drugs,” October 14, 1982, Politico (Oct. 14, 2010, 4:44 AM), https://www.politico.com/story/2010/10/reagan-declares-war-ondrugs-october-14-1982-043552 [https://perma.cc/38K6-3PCX].

62. Blanco, supra note 7 , at 397.

63. Adams \& Osborne, supra note 3, at 675.

64. Id.

65. Id.; see also Barbara Oudekerk \& Heather Warnken, Victim Service Providers in the United States, 2017, Bureau Just. Stat. 1 (Nov. 2019), https://www.bjs.gov/content/ pub/pdf/vspus17.pdf [https://perma.cc/K9ZK-6PZX] (reporting that there were 12,196 victim service providers in the United States as of 2017).

66. Oudekerk \& Warnken, supra note 65 , at 1 (reporting that 2,220 of the 12,196 victim service providers in the United States are found in prosecutors' offices). Prosecutor office programs tend to be "witness oriented," emphasizing "the importance of the victim as a witness for the case, while outside programs tend to be "victim oriented," providing "services to the victim immediately after the crime occurs." Robert A. Jerin, Laura J. Moriarty \& Melissa A. Gibson, Victim Service or Self-Service: An Analysis of Prosecution Based Victim-Witness Assistance Programs and Providers, 7 Crim. Just. Pol'y Rev. 142, 143 (1995); see also Dussich, supra note 58, at 490.

67. Henning, supra note 9, at 1111 (citing ТовоLowsky, supra note 50, at 7) (describing the Crime Victim Initiative, established by the Law Enforcement Assistance Administration in 1974).

68. Roberts, supra note 51, at 13-14; Jerin et al., supra note 66, at 142-43 (taking a close look at the victim-witness program structure in the state of North Carolina, which began via legislation in 1986).

69. Roberts, supra note 51, at 15; Jerin et al., supra note 66, at 148-50.

70. Roberts, supra note 51, at 15. 
right to participate in the criminal process. It developed the first victim impact statement in 1974 and secured the first victims' rights amendment, Proposition 8, in its state constitution in $1982 .{ }^{71}$ That same year, the President's Task Force on Victims of Crime gave the movement an injection of national energy when it declared that the "oppression [of crime victims by the justice system] must be redressed," and then proposed a federal constitutional amendment to protect the right of crime victims "to be present and to be heard at all critical stages of judicial proceedings." 72

While the federal constitutional amendment was ultimately defeated, many states followed California's lead in changing their laws to offer victims a voice in the process. Forty-four states now have victims' rights amendments in their state constitutions, ${ }^{73}$ every state has a statutory victims' bill of rights, ${ }^{74}$ and victim impact statements have received a stamp of approval from the U.S. Supreme Court. ${ }^{75}$ At the federal level, we see the imprint of the Victims' Rights Movement in the Victims of Crime Act, passed in 1984; $;^{76}$ the Violence Against Women Act, passed as part of the Violent Crime Control and Law Enforcement Act of 1994;77 and the expansion of victim services and trainings for federal law enforcement officers concerning the fair treatment of victims. ${ }^{78}$ The passage of the Antiterrorism and Effective Death Penalty Act of 1996, ${ }^{79}$ which radically altered habeas corpus rights for prisoners in both state and federal carceral facilities, grew out of the activities of victims' rights advocates. ${ }^{80}$

71. Adams \& Osborne, supra note 3 , at 675 . The following decade, California enacted the first anti-stalking law. Id. at 676 (citing Cal. Penal Code $§ 646.9$ (West 2008)).

72. President's TAsk Force on Victims of Crime, supra note 55, at 114.

73. By the end of the twentieth century, thirty-five states had constitutional provisions and all states had statutory enactments. See Cassell \& Garvin, supra note 5, at 106-07. By this Article's publication, nine more states had added constitutional provisions under Marsy's Law referenda. Similar Marsy's Law amendments were passed by Illinois, North Dakota, South Dakota, Ohio, Florida, Georgia, Nevada, North Carolina, and Oklahoma. Id. at $107 \mathrm{nn} .39-47$. California adopted Marsy's Law as Proposition 9 to amend Proposition 8 , which already provided state constitutional protection for victims' rights. Id. at 107 n.38.

74. Id. at 105 .

75. See Payne v. Tennessee, 501 U.S. 808, 825 (1991).

76. 42 U.S.C. $\$ 10606$ (repealed 2004).

77. Violence Against Women Act of 1994, Pub. L. No. 103-322, 108 Stat. 1902-55 (1994) (codified as amended in scattered sections of 8, 16, 18, and 42 U.S.C.).

78. Adams \& Osborne, supra note 3, at 680 (discussing activities of the Office for Victims of Crime (OVC)). These efforts built upon the Law Enforcement Assistance Administration grants to prosecutors' offices in the 1970s to develop victim/witness assistance bureaus. Roberts, supra note 51, at 13.

79. Antiterrorism and Effective Death Penalty Act of 1996, Pub. L. No. 104-132, 110 Stat. 1214 (1996) (codified as amended in scattered sections of 8, 18, 22, 28, and 42 U.S.C.); Adams \& Osborne, supra note 3, at 682 (discussing efforts of OVC in securing the bill's passage). As a result of this bill, OVC was able to create a reserve fund to support assistance to states in the event of domestic terrorism or events of mass violence. That fund provided support to the victims of the Oklahoma City courthouse bombing and victims of the Columbine High School shooting, as well as to victims of terrorist attacks that occurred on foreign soil. $I d$.

80. Scholars have recently classified these activities under the heading of "carceral feminism," a term first coined by Elizabeth Bernstein to denote the emphasis on law enforcement strategies to address issues of sexual assault and domestic violence. See Elizabeth Bernstein, The Sexual Politics of The New Abolitionism, 18 Differences: J. Feminist 
Taking a closer look at the state-level constitutional and statutory provisions enacted in recent decades, several features are common across jurisdictions. ${ }^{81}$ These enactments typically declare that victims have a right to receive notice of criminal proceedings, a right to attend or participate in those proceedings, a right to receive restitution, and a right to offer a victim impact statement before a sentence is imposed. ${ }^{82}$ The proceedings covered include most prominently, but not exclusively, bail and pretrial release hearings, the criminal trial itself, sentencing, and parole hearings. ${ }^{83}$ Victims also have a right to receive notice when the defendant is released or escapes from custody. ${ }^{84}$

For example, the Marsy's Law amendment recently enacted in Florida $^{85}$ gives victims, upon request: (1) "The right . . . to be present at all public proceedings involving the criminal conduct, including but not limited, to trial, plea, sentencing, or adjudication, even if the victim will be a witness at the proceeding, notwithstanding any rule to the contrary";86 (2) "The right to be heard in any public proceeding involving pretrial or other release from any form of legal constraint, plea, sentencing, adjudication, or parole, and any proceeding during which a right of the victim is implicated";87 and (3) "The right to confer with the prosecuting attorney concerning any plea agreements" or regarding "release, restitution, sentencing, or any other disposition of the case." 88 Florida victims also have

Cultural Stud. 128-51 (2007). For recent contributors to the conversation about the reach, implications, and contradictions of carceral feminism, see Anna Terwiel, What Is Carceral Feminism?, 48 Pol. Theory 421 (2020), and Aya Gruber, The Feminist War on Crime: The Unexpected Role of Women's Liberation in Mass Incarceration (2020).

81. See Henning, supra note 9, at 1111 (describing the "typical victims' rights statute").

82. Id. at $1117-18$.

83. The right to attend the criminal trial sometimes conflicts with the defendant's right to due process, which allows for the exclusion of witnesses before their testimony is taken. See Mosteller, supra note 4, at 457. The due process protection ensures that later witnesses cannot shape their testimony to match the testimony of prior witnesses. See id. Prosecutors can avoid this tension by having the victim testify first. Id.; see also Henning, supra note 9, at 1154 (describing various ways in which putative victims' rights might compromise the rights of defendants).

84. Henning, supra note 9, at 1117.

85. Not all victims' rights advocates have been supportive of Marsy's Law constitutional amendments. See, e.g, Laurie Schipper \& Beth Barnhill, We're Victims' Rights Advocates, and We Opposed Marsy's Law, ACLU (May 16, 2018, 10:45 AM), https:// www.aclu.org/blog/criminal-law-reform/were-victims-rights-advocates-and-we-opposedmarsys-law [https://perma.cc/WW9Z-8QRK]. Moreover, some percentage of victims would like the criminal legal system to focus more broadly on rehabilitation over punishment. All. FOR SAFETY \& JUST., supra note 6, at 15 (reporting that victims expressed a preference for rehabilitation over punishment by a two-to-one margin). Victims who would like the prosecutor's office to take a softer approach-to offer diversion to a defendant where the program guidelines don't allow it based on the defendant's crime or criminal historyare likely to be told that their only chance for input is at the sentencing hearing following conviction.

86. Fla. Const. art. I, $\S 16(b)(6)(a)$. Cassell and Garvin note that this provision, as well as the others following, is similar to the language found in "many other states' constitutional and statutory provisions," as well as provisions of federal law, such as the Violence Against Women Act and 18 U.S.C. § 3771(a)(1). Cassell \& Garvin, supra note 5, at 109.

87. Id. § 16(b)(6)(b).

88. Id. § 16(b)(6)(c). 
" $[\mathrm{t}]$ he right to proceedings free from unreasonable delay, and to a prompt and final conclusion of the case and any related postjudgment proceedings"89_a right that might squarely conflict with defense or prosecution requests for continuances in furtherance of better preparation-and a "right ... to be reasonably protected from the accused and any person acting on behalf of the accused." 90 The amendment further promises victims that their welfare will be taken into account by the judge when setting bail or pretrial release conditions; ${ }^{91}$ that they will receive "reasonable, accurate, and timely notice" of the offender's release or escape; 92 and that the scope of protection from the defendant extends beyond physical violence to include "intimidation, harassment, and abuse." 93 Finally, the amendment assures victims that they have a "right to full and timely restitution in every case and from each convicted offender for all losses suffered, both directly and indirectly, by the victim as a result of the criminal conduct," 94 thereby imposing joint and several liability on all co-defendants for all losses. Notably, Florida courts have long recognized that defendants who cannot pay the full amount, despite bona fide efforts to do so, are required "to pay only as much as they can reasonably afford." 95

While the rights listed are quite extensive, the remedies for violations of these provisions, whether statutory or constitutional, are often more illusory than real. ${ }^{96}$ For example, under Florida's Marsy's Law victims do not have the ability to get a defendant's conviction or sentence reversed or declared null simply because they were excluded from the proceedings. Further, victims do not have the right to obtain money damages for a rights violation committed by the court or prosecutor, nor can victims seek writs of mandamus to force trial courts to take their feelings into account during sentencing. In the absence of real remedies, the "institutionalized disinterest" of prior decades may have been transformed into benign neglect by judges and prosecutors who were too busy or too distracted to give victims their due. ${ }^{97}$ Florida sought to address these en-

89. Id. § 16(b)(10).

90. Id. § 16(b)(3).

91. Id. $\S 16(\mathrm{~b})(4)$.

92. Id. § 16(b)(6)(a).

93. Id. $\S 16(\mathrm{~b})(2)$.

94. Id. $§ 16(\mathrm{~b})(9)$.

95. Cassell \& Garvin, supra note 5, at 131 (citing Bourget v. State, 634 So. 2d 1109, 1110 (Fla. Dist. Ct. App. 1994)).

96. Id. at 105 (noting that many state statutes and constitutional amendments "lacked effective enforcement mechanisms to ensure that victims' rights were fully implemented").

97. See Mosteller, supra note 4, at 449 ("[O]fficials fail to honor victims' rights largely as a result of inertia, past learning, insensitivity to the unfamiliar needs of victims, lack of training, and inadequate or misdirected institutional incentives."); Laurence H. Tribe \& Paul G. Cassell, Embed the Rights of Victims in the Constitution, L.A. Times (July 6, 1998, 12:00 AM), https://www.latimes.com/archives/la-xpm-1998-jul-06-me-1150-story.html [https://perma.cc/D5ZR-WXZA] (noting that enactments "come into conflict with bureaucratic habit, traditional indifference, [or] sheer inertia"). Gillis and Beloof contend that because prosecutors "represent the people of their state, not the individual crime victim," we ought not to expect prosecutorial enforcement of victim rights. John W. Gillis \& Doug- 
forcement issues by authorizing victims, their attorneys, and prosecutors to "assert and seek enforcement of the rights enumerated ... as a matter of right" and giving them standing to do so. ${ }^{98}$ South Dakota has done so by authorizing the creation of a "Marsy's Card" to be given to victims of crime by police. ${ }^{99}$ Whether those pronouncements are sufficient to overcome bureaucratic and professional inertia remains to be seen.

\section{THE COLLISION COURSE BETWEEN DIVERSION AND VICTIMS' RIGHTS}

While the Victims' Rights Movement has made notable advances to change the public face of crime victim involvement in the legal system, it has not fundamentally changed the Supreme Court's declaration that victims have no "judicially cognizable interest" in the prosecution or nonprosecution of a given case. ${ }^{100}$ In light of that status, how should prosecutors account for victim interests in the pursuit or non-pursuit of diversion? The hallmark of the Victims' Rights Movement is the assertion that victims should not be ignored, but their interests and opinions might run counter to diversion program interests in fiscal responsibility, proportionality across cases, and compassion for low-level offenders. They might even prioritize retribution at the expense of all other goals. In the event of a conflict, should victim interests be permitted to undercut the systemic interests that support diversion?

There are two primary areas in which victim concerns might emerge and potentially conflict with the principles that underlie diversion programs. The first issue is victim input into the diversion offer. As discussed in Part II, prosecutors design eligibility standards for their diversion programs and then subject all eligible defendants to suitability review to limit the number of defendants who can take advantage of diversion, thereby increasing the likelihood of program success. ${ }^{101}$ The question here is whether the victim ought to be consulted as part of that eligibility or suitability review process, and more importantly, whether prosecutors ought to regard the victim's consent to diversion as a necessary predicate to making the diversion offer. The second issue is restitution-if the offender's crime has caused damage to the victim's property, loss of money, or injury, the victim is entitled to restitution. That restitution amount ordinarily would be ordered as a term of the sentence if the case were fully prosecuted and a conviction resulted; in fact, right to restitution has been

las E. Beloof, The Next Step for a Maturing Victim Rights Movement: Enforcing Crime Victim Rights in the Courts, 33 McGeorge L. Rev. 689, 695 (2002). In fact, prosecutors may be legally precluded from representing the victim due to state standing doctrines; because victim advocates typically work for the prosecutor's office, they would be similarly constrained. $I d$.

98. Fla. Const. art. I, § 16(c).

99. S.D. Const. art. VI, § 29, cl. 19 (describing the Marsy's Card).

100. Linda R.S. v. Richard D., 410 U.S. 614, 619 (1973).

101. See supra Part II. 
a mainstay of the Victims' Rights Movement, as discussed in Part III.102 But the whole point of diversion is to avoid the regular adjudicatory process and to have the case end short of conviction. For that reason, the question of how victims will be compensated for their losses when the case ends in diversion must be considered. I discuss each of those issues in turn below.

\section{A. Victim Input into the Diversion Offer}

In this Section, I consider the extent to which prosecutors should listen to the victim when deciding whether to offer diversion to an otherwise eligible defendant. The Victims' Rights Movement has endeavored to make consultation with victims a regular part of prosecution practice. Recall the language of Florida's Marsy's Law, discussed in Part III: the victim has "[t]he right to confer with the prosecuting attorney concerning any plea agreements" and case resolution. ${ }^{103}$ But diversion is neither a plea agreement nor a case resolution; it is the path by which the defendant avoids those outcomes and is given a second chance. Ought the victim have a say in whether diversion is offered to or withheld from an eligible defendant? If the victim refuses to consent, should the prosecutor take diversion off the table?

At first glance this might not seem like much of an actual problem because jurisdictions have established diversion programs mostly to provide an alternative for persons who are accused of low-level offenses that have no specific victims, such as drug offenses, prostitution, or driving offenses. In the absence of a specific victim advocating for his or her rights, one might conclude that the risk of a collision between diversion and an assertive victim is almost nonexistent. That conclusion would underestimate the risk for three reasons. First, even in crime-category-based programs, diversion is not exclusively limited to victimless crimes. Some jurisdictions provide diversion for various forms of theft, which is a victim-based offense, ${ }^{104}$ and others extend diversion to certain felony offenses with victims. ${ }^{105}$ Moreover, drug offenders often come into drug diversion for drug-related offenses (offenses committed to support the drug user's consumption), ${ }^{106}$ and many of those offenses have victims.

102. See supra Part III.

103. Fla. Const. art. I, § 16(b)(6)(c).

104. See Rempel Et AL., supra note 17, at 17 (reviewing a program for property and drug offenses in Minneapolis and a similar program in Dallas for retail theft offenses); Lepage \& May, supra note 25, at 12 (reviewing a program for first-time property offenders in Anchorage).

105. See Lowry \& Kerodal, supra note 27, at 14-15.

106. Daniela Barberi \& Faye S. Taxman, Diversion and Alternatives to Arrest: A Qualitative Understanding of Police and Substance Users' Perspective, 49 J. DRug Issues 703 , 705 ("Substance users typically engage in a range of criminal behaviors to support their habits and/or lifestyles such as drug use, possession of paraphernalia, public urination, petty thefts, property crimes, and shoplifting."). Andrea Yatsco and her colleagues similarly identify the connection between drug use and crime: "Justice-involved individuals are overrepresented within substance abuse disorder (SUD) treatment when compared to the general population ... . " Andrea J. Yatsco, Rachel D. Garza, Tiffany Champagne-Lan- 
Lastly, the programs geared toward juveniles and those with mental health disorders address all kinds of offenses, including those with traditional victims. ${ }^{107}$ Hence, the number of victims who might influence the frequency and distribution of diversion resources is far greater than the program labels alone would suggest. ${ }^{108}$

Having established that some number of potential diversion cases will involve victims, the next step is to decide the proper level of victim input. It could range from the prosecutor providing the victim advance notice that a diversion offer will be made to the defendant (notice schemes), to the prosecutor offering the victim a chance to weigh in on that offer before it is communicated (consultation schemes), or even to the prosecutor needing the victim's consent before making the offer, thus granting the victim a veto if she disagrees (veto schemes). In veto schemes, a victim who withholds consent effectively keeps an otherwise eligible and suitable offender from being able to participate in diversion, thus sending him down the full prosecution track. The level of victim input in the diversion decision might be a feature of the state statute authorizing diversion generally, or it might be a feature of the particular diversion program created by the prosecutor's office. ${ }^{109}$

Notice and consultation schemes fully embrace the message of the Victims' Rights Movement and ought to be supported. They treat the victim with dignity and respect because they acknowledge that, even without a

gabeer \& James R. Langabeer, Alternatives to Arrest for Illicit Opioid Use: A Joint Criminal Justice and Healthcare Treatment Collaboration, Substance Abuse: Rsch. \& Treatment 1, 1 (2020).

The correlation between substance abuse and criminality has also been observed by police officers in rural Illinois: "Frequent flyers come in all the time for not only drug-related crimes but associated crimes and it wasn't stopping and the population was growing ... [When we started to] take a couple of these people to treatment .... some of these other crimes, along with the drug crimes, start[ed] slowing down around our area." JessicA Reichert, Lily Gleicher, Lynne Mock, Sharyn Adams \& Kimberly Lopez, PoliceLed Referrals to Treatment for Substance Use Disorders in Rural Illinois 21 (2017).

107. For a sample of the literature about juvenile and mental health programs, see generally Craig S. Schwalbe, Robin E. Gearing, Michael J. Mackenzie, Kathryne B. Brewer \& Rawan Ibrahim, A Meta-Analysis of Experimental Studies of Diversion Programs for Juvenile Offenders, 32 Clinical Psych. Rev. 26 (2011); Holly A. Wilson \& Robert D. Hoge, The Effect of Youth Diversion Programs on Recidivism: A Meta-Analytic Review, 40 CRIM. Just. \& Behav. 497 (2013); Francis Pakes \& Jane Winstone, Effective Practice in Mental Health Diversion and Liaison, 48 How. J. 158 (2009); Alexander J. Cowell, Nahama Broner \& Randolph Dupont, The Cost-Effectiveness of Criminal Justice Diversion Programs for People with Serious Mental Illness Co-Occurring with Substance Abuse, $20 \mathrm{~J}$. CONTEMP. CRim. Just. 292 (2004).

108. Even for crimes we think of as "victimless," sometimes the neighborhood is invited to comment on the impact of the defendant's behavior generally. Henning, supra note 9, at $1145,1164$.

109. See, e.g., OKLa. Stat. tit. 22, § 991f-1.1(B)(3)(g) (2009) (providing that the victim's position on diversion should be taken into account during eligibility determination); Pretrial Diversion: About the Program, Совв CNTY. Gov'T, https://www.cobbcounty.org/ courts/district-attorney/pretrial-diversion [https://perma.cc/526T-WH6Y] (providing that the victim's response to a defendant's petition for diversion will be considered at the eligibility stage, along with the nature of the crime and the defendant's criminal history). 
legally cognizable interest in the case,${ }^{110}$ the victim has an actual interest in the case. Diversion, if successful, results in no conviction and no punishment for the alleged offender, an outcome that might upset the victim. Moreover, a defendant who receives diversion will be living out in the community while fulfilling the terms of the program, and the communitybased treatment setting may put some victims on edge. For both of these reasons, victims need to know up front that diversion is being considered, and they should be consulted about whether the person who caused harm ought to be (1) given the chance to resolve the case without punishment and (2) released back into the community while doing service or education work in support of rehabilitation. Surely not every victim will have an opinion, and surely not every victim with an opinion will oppose these goals, but prosecutors ought not to assume that they know the victim's perspective. Prosecutors need to ask questions, and they need to listen carefully as victims express their opinions. In short, while giving the victim notice and an opportunity to confer on the issue of diversion might not appear in the language of statutory or constitutional provisions addressing victims' rights, ${ }^{111}$ it is fully consistent with their spirit.

Veto schemes are a different animal altogether. Prosecutors should not allow the victim's opinion to control their decision making. In our landscape of public prosecution, we trust public officials to make decisions of consequence because they are presumed to be professional and disinterested. ${ }^{112}$ We believe that prosecutors' disinterest-coupled with their institutional knowledge and experience across hundreds or thousands of cases-properly calibrates their barometer of justice. Victims lack both this level of experience and this objectivity, and thus are likely to either over- or under-estimate how bad this crime (or offender) is when compared to other crimes (or offenders) in the jurisdiction. As noted by Paul Robinson, "victim influence is inconsistent with our reasons for being so careful to have impartial judges, jurors, and prosecutors"-persons who will "not be swayed by a personal stake in [the outcome]"- -serve as the ultimate decision makers. ${ }^{113}$ He continues on in the context of plea bargaining: "If we think a prosecutor's personal stake in a case ought to disqualify him or her, on what grounds could we justify allowing the most

110. Linda R.S. v. Richard D., 410 U.S. 614, 619 (1973).

111. Several states do mention the consultation right in connection with diversion in their statutory schemes. See, e.g., Del. CodE AnN. tit. 11, § 9405 (West 2021) (providing for a right to consult with the prosecutor before the prosecutor agrees to diversion); MinN. STAT. ANN. §§ 611A.03-.0301 (West 2021) (providing for a right to object to pretrial diversion); 18 Pa. Stat. And Cons. Stat. AnN. § 11.201(4) (West 2019) (providing for a right to comment before diversion). At the federal level, the victim has the right to be informed of a plea bargain or deferred prosecution agreement, pursuant to the Crime Victims' Rights Act. 18 U.S.C. \& 3771(a)(9). This provision requires neither up-front notification nor time to confer with the U.S. Attorney about the decision, however. See id.

112. Bruce A. Green, Why Should Prosecutors "Seek Justice"?, 26 Fordham Urb. L.J. 607, 614 (1999).

113. Paul H. Robinson, Should the Victims' Rights Movement Have Influence over Criminal Law Formulation and Adjudication?, 33 McGeorge L. Rev. 749, 756 (2002). 
interested party - the victim - to have a veto . . ? "114

As Professor Robinson's comments signal, if we allow the diversion decision to hinge on the victim's consent, that decision may be arbitrary. It might rest on nothing more than whether the victim is forgiving or vengeful ${ }^{115}$ or whether the victim has the "means and the interest to actively press" his or her views on a prosecutor who disagrees. ${ }^{116}$ Victims have sought the veto power in the context of plea offers, ${ }^{117}$ but currently no state extends this power to individual victims when it comes to plea agreements that the prosecutor has negotiated. Victims likewise lack the power to force prosecutors to confer with them about their declination decisions, although consultation with victims is often considered a wise practice for public relations in prosecutors' offices. ${ }^{118}$

Moreover, to the extent that the Supreme Court has validated the consideration of victim impact evidence at the sentencing stage as a mechanism to assess the severity of the offender's conduct, ${ }^{119}$ these concerns are misplaced when diversion is the issue under discussion. Diversion is primarily a rehabilitative system, not a retributive one; yielding to victim concerns for retribution at this juncture would upend the diversion protocols that were put in place to serve other interests. The offender's need for and amenability to treatment or services and the system's need to conserve resources guide the use of diversion programs. But if we offer the victim veto power, emotional appeals by the victim might trump the offender's rehabilitative potential. ${ }^{120}$

Aside from the institutional design objection, empirical work shows that even in an era of victims' rights, prosecutors maintain the upper hand in the prosecutor-victim relationship through savvy communication tech-

114. Id. at $756-57$.

115. Susan Bandes has cautioned that victim input can foreground vengeance and bigotry, which then reduces the decision-maker's ability to perceive "the essential humanity of the defendant." Susan Bandes, Empathy, Narrative, and Victim Impact Statements, 63 U. Chi. L. Rev. 361, 365-66 (1996).

116. Robinson, supra note 113 , at 757 . Concerns about the arbitrariness of victim input were voiced by the Supreme Court in Booth v. Maryland, 482 U.S. 496, 505-06 (1987), a case prohibiting the use of victim impact evidence in death penalty cases for due process reasons. But Booth was overturned four years later in Payne v. Tennessee, 501 U.S. 808, 823 (1991), when the Court concluded that the factfinder should be allowed to consider victim impact evidence as part of the moral blameworthiness of the offender.

117. See, e.g., George P. Fletcher, With Justice for Some: Victims' Rights in Criminal Trials 193 (1995).

118. Zulkifl M. Zargar, Secret Faits Accomplis: Declination Decisions, Nonprosecution Agreements, and the Crime Victim's Right to Confer, 89 Fordham L. Rev. 343, 375-76 (2020). Victim consent to a defendant's access to drug court (or other problem-solving court) presumably poses many of the same concerns, but that is beyond the scope of this paper.

119. See Payne, 501 U.S. at 827.

120. One author describes a story from her own practice background, in which a prosecutor was so swayed by a victim's narrative that she refused to dismiss a juvenile case that clearly warranted dismissal on substantive justice grounds. Henning, supra note 9, at 1139. She explains, "Notwithstanding her own stated doubt about the child's need for further services, the prosecutor felt compelled to follow the wishes of the victim, who wanted the child not only prosecuted but incarcerated in a local detention facility." Id. 
niques. Prosecutors often talk victims into doing what the prosecutor wants without saying so in a straightforward manner. Work by Lisa Frohmann has established the following patterns of "victim management." 121 If the prosecutor wants to dismiss a case or offer a lenient plea deal to foster early resolution, the prosecutor emphasizes to the victim the challenges of testifying, particularly during cross-examination, and sows the seeds of concern about the victim's safety if she presses forward. ${ }^{122}$ If the prosecutor wants to go forward in the face of victim resistance, the prosecutor uses language of support and reassurance, offering to protect the victim from the defense attorney during cross examination and to provide witness protection outside the courthouse. ${ }^{123}$ The same approach to victim management has been shown with respect to diversion programs. In Chicago, for example, where prosecutors are required by office policy to get victim consent, they admit that they are able to talk the victims into consenting without much effort. ${ }^{124}$ This evidence might suggest that we ought not to worry about affording victims veto power over the diversion decision because it will not ultimately prove to be much of a roadblock. Nonetheless, enacting a right as an empty formality does not serve the interests of justice and is likely to lead to victim dissatisfaction in the long run.

\section{B. Restitution}

Like the right to confer with the prosecutor, the victim's right to receive restitution is traditionally tied to conviction and adjudication in the statutory and constitutional victims' rights provisions discussed in Part III. ${ }^{125}$ As diversion is not conviction or adjudication, but is rather a concerted effort to avoid those outcomes, how should restitution be handled in the diversion context?

State statutes and prosecutor office policies make clear that the victim's right to receive restitution for losses incurred as a result of the offender's behavior should be respected in the diversion arrangement, even though there is no conviction for the offense. ${ }^{126}$ Because diversion is more of a second chance than an escape from accountability, the defendant ought not to be relieved of his restitution obligations simply because he is afforded a second chance through the program. The loss amount is the same, and presumably the offender's responsibility for causing the loss is the same, even though he has not yet been convicted of the offense. Mak-

121. See generally Lisa Frohmann, Constituting Power in Sexual Assault Cases: Prosecutorial Strategies for Victim Management, 45 Soc. Probs. 393 (1998).

122. Id. at 396.

123. Id. at 396-98.

124. See Dewan \& Lehren, supra note 40.

125. See, e.g., Fla. Const. art. I, § 16(b)(9) (providing that the victim is entitled to "full and timely restitution in every case and from each convicted offender for all losses suffered, both directly and indirectly, by the victim as a result of the criminal conduct" (emphasis added)).

126. See id.; Or. Rev. Stat. Ann. $\$ 137.108$ (West 2013); Okla. Stat. Ann. tit. 22, $\S$ 991f-1.1 (West 2021); Wash. Rev. Code Ann. § 13.40 .080 (West 2018). 
ing the victim whole may even be an important part of the rehabilitative effort. However, the means by which restitution is collected can vary significantly between jurisdictions, with differing impacts on a defendant's ability to participate in diversion at all.

A program might require the defendant to make periodic restitution payments during the diversionary period. This is the approach adopted in Oregon ${ }^{127}$ and Oklahoma ${ }^{128}$ and in the city of Tucson, Arizona, ${ }^{129}$ for example. A program might further address what will happen if the diversionary period ends before a balance is paid in full. In the state of Washington, for instance, the defendant must pay restitution as a term of diversion, but if at the end of the diversionary period there remains an unpaid balance, the court will enter an order giving the defendant ten years from the end of the diversion program to pay it off. ${ }^{130}$

At the extreme, a program might require the defendant to pay the full amount of restitution up front, such that inability to pay renders ineligible a defendant who otherwise meets the criteria for the program based on offense and criminal history. Such a system is currently in effect in Cobb County, Georgia, where payment of the entire restitution amount up front is a formal condition of eligibility in the program designed by the prosecutor's office. ${ }^{131}$ This payment requirement is contained in a provision on the prosecutor's office website that otherwise addresses administrative fees of the program, drug screening costs, and reimbursement for appointed counsel, if applicable. ${ }^{132}$ The program statement mentions that the administrative fees might be paid in installments if approved by the program coordinator, but makes no such reference to the restitution amount. ${ }^{133}$

The full-payment-up-front approach does have several benefits. It eliminates uncertainty for the victim about whether he or she will ever be reimbursed. It also eliminates the risk of delay because full reimbursement comes immediately. Moreover, the offender's willingness to pay the full amount up front demonstrates a high level of commitment to the program, which may be a strong indicator of likely success later on.

But the downsides of the full-payment-up-front approach are deeply troubling. First and foremost, it discriminates against poor defendants and those who live paycheck-to-paycheck because these defendants are simply unable to pay large sums all at once. In so doing, it keeps them from being able to take advantage of the second chance that diversion provides to wealthier defendants. Poor defendants might be very strong candidates for the program based on enthusiasm, personal commitment,

127. Or. Rev. Stat. Ann. $\$ 137.108$ (West 2013).

128. OKLa. Stat. Ann. tit. 22, § 991f-1.1(F)(1) (2021).

129. Prosecutor's Office: Diversion, CITY OF Tucson, https://www.tucsonaz.gov/prosecutor/diversion [https://perma.cc/KRL3-CD4S].

130. Wash. Rev. Code Ann. § 13.40.080(5)(c) (West 2018).

131. Pretrial Diversion: About the Program, supra note 109.

132. Id.

133. Id. 
and family support, but lack of cash will prevent them from being considered. The wealth of a defendant should not determine his or her access to leniency, ${ }^{134}$ particularly given the range of collateral consequences postconviction. ${ }^{135}$

Secondly, because so many defendants fall into this disadvantaged group, most victims will not receive their money (at least not in a timely fashion) if we insist on up-front payment. Defendants who are deemed ineligible for financial reasons will have their cases put on the regular court calendar, some of them will be remanded to custody, and it may take months or years for their cases to resolve. In the meantime, victims won't receive a dime. If the case finally ends in conviction, the court will order restitution, but it may take months or years for defendants to make payments, especially if they end up serving jail time. ${ }^{136}$ And data shows that most restitution awards are never paid in full as a term of probation ${ }^{137}$ because most defendants still do not have the means to pay. If diversion excludes all of those who do not have a lump sum of money at the ready, many victims will be forced to wait for months or years to receive money that has been ordered but is not forthcoming.

Finally, establishing full-payment-up-front requirements for eligibility further exacerbates the selection bias described in Part II. ${ }^{138}$ Wealthier defendants come to diversion opportunities with more resources to succeed in the program than do poorer defendants. If only wealthy defendants are admitted to programs because of this screening device, then prosecutors have effectively put their thumbs on the scales to ensure program success; they have created a greater likelihood of establishing program success by choosing only those participants who are already well positioned to achieve success. In other words, a program that enrolls only wealthy defendants tells us very little about the effect of the treatment (i.e., the program) on changing the long-term behavior of the defendants.

Payment plans for restitution are a common feature of post-adjudication court orders, even in the wake of Marsy's Law constitutional amend-

134. See United States v. Kuhlman, 711 F.3d 1321, 1329 (11th Cir. 2013) (finding an abuse of discretion where the trial court gave a defendant a downward departure for full payment of $\$ 3$ million in restitution, because it offered a reduced sentence to the defendant merely because he could pay this amount quickly).

135. See Aneja \& Avenacio-León, supra note 23, at 44.

136. See Bruce Western, The Impact of Incarceration on Wage Mobility and Inequality, 67 Ам. Socio. Rev. 526, 527 (2002) (documenting the effects of incarceration on earning capacity).

137. Data suggests restitution orders are rarely paid in full. U.S. Gov'T ACCOUNTABILity Off., GAO-18-203, Federal Criminal Restitution: Most Debt is Outstanding And Oversight of Collections Could Be Improved 22-23 (2018) (noting most of outstanding debt is uncollectable due to offenders' inability to pay); OFFICE FOR VICTIMS of Crime, U.S. Dep't of Just., New Directions from the Field: Victims' Rights and Services for the 21st Century 357 (1998); Restitution, W. Dist. OF N.Y., https:// www.justice.gov/usao-wdny/restitution [https://perma.cc/C67Y-KN2S] (commenting specifically on defendant's inability to pay while incarcerated).

138. See supra Part II. 
ments. ${ }^{139}$ Courts recognize that defendants should be expected to pay only as much as they can reasonably afford. Recent efforts toward bail reform and limiting the use of fines and fees point in a similar direction: offenders should not be disadvantaged based on ability to pay, lest we risk turning our jails into debtors' prisons. ${ }^{140}$ The growth of victim compensation schemes recognizes this fact; they provide funds to victims to reimburse costs using tax dollars or court-assessed fees rather than requiring the defendant to pay directly. ${ }^{141}$ What is more, policymakers are increasingly admitting the detrimental effects of criminal convictions on earning capacity - the very thing that diversion aims to prevent - which would impede the defendant's ability to reimburse the victim for the damage caused. ${ }^{142}$ For all of these reasons, a program that makes second chances available only to the wealthiest defendants is not truly committed to compassion, fiscal responsibility, or proportionality. ${ }^{143}$

The bottom line is this: if we make full payment of restitution a term of diversion eligibility, rather than a feature of the program itself, we establish a system in which opportunity for mercy is determined, first and foremost, by wealth. This approach undermines diversion's principal aim of creating a pathway out of the legal system in order to provide proportionate, fiscally responsible, and compassionate services to a large portion of the offender population. Moreover, in a system where diversion is tied to up-front payment, the number of cases funneled out of the system will be dramatically reduced, the number of victims who receive compensation will be limited, and our ability to gauge the effectiveness of the program itself will be curtailed. The embroidery of "respect for victims" created by

139. Cassell \& Garvin, supra note 5, at 129-31 (citing Bourget v. State, 634 So. 2d 1109, 1110 (Fla. Dist. Ct. App. 1994)).

140. For a sampling of this literature, see generally Wayne A. Logan \& Ronald F. Wright, Mercenary Criminal Justice, 2014 U. ILl. L. Rev. 1175 (2014); Neil L. Sobol, Charging the Poor: Criminal Justice Debt \& Modern-Day Debtors' Prisons, 75 MD. L. Rev. 486 (2016); Laura I. Appleman, Nickel and Dimed into Incarceration: Cash-Register Justice in the Criminal System, 57 B.C. L. Rev. 1483 (2016); and John Logan Koepke \& David G. Robinson, Danger Ahead: Risk Assessment and the Future of Bail Reform, 93 WAsH. L. REv. 1725 (2018).

141. Funding victim compensation programs just through tax dollars or court assessments is not without controversy; some victims believe that this funding approach relieves the defendant of all responsibility to pay for losses he caused. See, e.g., Matt Markovich, A 'free ride'?: King Co. Taxpayers to Pay Back Some Crime Victims in New Program, KOMO News (Nov. 24, 2020), https://komonews.com/news/operation-crime-justice/new-kingcounty-program-will-use-taxpayer-money-to-support-crime-victims [https://perma.cc/ 8YQ3-JD38].

142. Terry-Ann Craigie, Ames Grawert, Cameron Kimble \& Joseph E. Stiglitz, Conviction, Imprisonment, and Lost Earnings, BRENNAN CTR. FOR Just. (Sept. 15, 2020), https:// www.brennancenter.org/our-work/research-reports/conviction-imprisonment-and-lostearnings-how-involvement-criminal [https://perma.cc/WZ95-379C].

143. Wealth effects cannot be completely eliminated from the criminal courts, as defendants with means can hire private counsel while indigent defendants cannot. But wealth does not determine who has a right to counsel in the first place. Johnson v. Zerbst, 304 U.S. 458, 462 (1938) (providing right to counsel in federal court under the Sixth Amendment); Gideon v. Wainwright, 372 U.S. 335, 344-45 (1963) (providing right to counsel in state courts under the Sixth Amendment). 
a full-restitution-up-front requirement is too delicate to withstand these costs.

\section{CONCLUSION}

In this Article, I have illuminated two problems that surface at the intersection between diversion programming and calls for enhanced victims' rights in the United States. These points of concern are the proper level of victim input into the diversion offer and the mechanism for making restitution payments to the victim. I have argued that while the prosecutor ought to account for the victim's position when deciding both whether to make the diversion offer to an eligible defendant and how to structure restitution payments, systemic interests in the fiscal soundness of the diversion program and our commitment to fairness and compassion must remain paramount. Prosecutors who excessively defer to victim opinions risk causing "distortions of justice" that dilute the moral credibility of the legal system. ${ }^{144}$ Instances of deference might assuage particular victims in the short term, but over the long run they cause a crisis of legitimacy for criminal legal institutions writ large and threaten to undermine the entire diversion enterprise.

A program that rests ultimate decisions about diversion eligibility on a victim's individual preference or a defendant's immediate ability to pay is at odds with the sense of objectivity and critical distance that ought to guide decisions of this sort. Conditioning program participation on the consent of a particular victim risks introducing a form of arbitrariness into the justice system at a time when we ought to embrace fairness and transparency. Likewise, requiring full payment of restitution up front creates a barrier to entry for defendants on the basis of wealth, and ultimately limits the number of victims who will receive any money for their losses. Neither outcome can be justified by the call for increased victims' rights.

Improved respect for and treatment of victims remains a laudable goal. But achieving this goal will require greater resources and attentiveness by prosecutors and judges ${ }^{145}$ instead of more formal law or diversion eligibility requirements, ${ }^{146}$ particularly if those requirements place defendants' constitutional rights and state budgets in jeopardy. "[E]veryday coopera-

144. Robinson, supra note 113, at 757; see also Henning, supra note 9, at 1142 (warning that excessive attention to victims" rights will "distort the balance" between rehabilitation and accountability).

145. Schipper \& Barnhill, supra note 85 . For example, prosecutors could embrace performance metrics that help them track how often and how frequently they connect with victims in a given case, see, e.g., Protecting \& Serving Victims, Prosecutorial PerformANCE INDICATORS, https://prosecutorialperformanceindicators.org/protecting-serving-victims/ [https://perma.cc/2T66-YR5T], or encourage victims to participate in restorative justice programs to share their feelings about the crime with the offender in a more productive setting, see Henning, supra note 9, at 1162-64.

146. Mosteller, supra note 4, at 444-45. 
tion" 147 will get us further than victims' rights assertions that ignore the consequences felt by or costs imposed on other justice system actors. Recognizing a sense of "inner-connectedness is especially important, because as Miriam Krinsky and Liz Komar emphasize in their contribution to this volume, the line that separates the defendant population from the victim population is often porous rather than solid.

Diversion programs emerged after decades of conventional law and order approaches decimated state coffers, destroyed inner city populations, and diminished respect for criminal justice institutions. We have only just recently begun to emerge from that crater, and we cannot afford, financially or morally, to go backwards, not even in the name of victims' rights.

147. Jonathan M. Metzl, Dying of Whiteness: How the Politics of Racial Resentment is Killing America's Heartland 19 (2019). 